Jurnal KIBASP (Kajian Bahasa, Sastra dan Pengajaran)

Volume 3, Nomor 1, Desember 2019

e-ISSN : 2597-5218

p-ISSN : 2597-520X

DOI : https://doi.org/10.31539/kibasp.v3i1.864

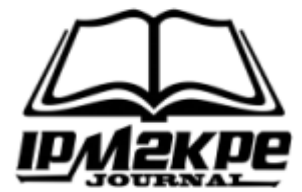

\title{
KONTEKSTUALITAS MODUL MATAKULIAH PEWARA PADA MAHASISWA PROGRAM STUDI BAHASA INDONESIA
}

\author{
Agung Nugroho', Syaiful Abid ${ }^{2}$ \\ STKIP-PGRI Lubuklinggau ${ }^{1,2}$ \\ agungaryonugroho886@gmail.com ${ }^{1}$
}

Submit, 28-09-2019 Accepted, 26-12-2019 Publish, 26-12-2019

\begin{abstract}
ABSTRAK
Tujuan penelitian untuk mengetahui proses pengembangan modul matakuliah pewara berbasis kontekstual mahasiswa program studi pendidikan bahasa dan sastra Indonesia STKIP-PGRI Lubuklinggau. Metode yang digunakan penelitian Research and Development (R\&D) model Dick \& Carey dengan tahapan, 1) analisis kebutuhan dan tujuan; 2) analisis pembelajaran; 3) analisis pembelajaran (mahasiswa) dan konteks; 4) merumuskan tujuan performansi; 5) mengembangkan instrument; 6) mengembangkan strategi pembelajaran; 7) mengembangkan dan memilih bahan pembelajaran; 8) merancang dan melakukan evaluasi formatif; 9) melakukan revisi; 10) evaluasi sumatif. Hasil penelitian, persentase dari angket uji coba kelompok kecil sebesar 92,78\% masuk dalam kategori sangat positif. Uji coba kelompok besar berdasarkan angket yang diberikan kepada siswa mendapatkan respon sangat postif dengan persentase $91,15 \%$, hasil tes kemampuan siswa setelah menggunakan modul mata kuliah pewara sebanyak 10 orang memperoleh nilai sangat baik dengan skor $8-10$ jumlah persentase sebanyak $38,46 \%$, sebanyak 8 orang yang memperoleh nilai 6,6 - 7,9 dengan kategori baik dan persentase sebesar $30,77 \%$, jumlah mahasiswa yang memperoleh nilai cukup hanya 4 orang dengan skor 6 atau hanya 15,38\%, dan mahasiswa yang memperoleh nilai kurang sebanyak 4 orang dengan rentang nilai 4,6 - 5,5 atau sebesar 15,38\%. Simpulan, pengembangan modul matakuliah pewara berbasis kontekstual mahasiswa program studi pendidikan bahasa dan sastra Indonesia dalam kategori sangat baik dan praktis untuk digunakan mahasiswa.
\end{abstract}

Kata Kunci: Kontekstualitas, Modul, Matakuliah Pewara.

\section{ABSTRACT}

The purpose of this research is to find out the process of developing contextual lecturer modules based on contextual students of the Indonesian language and literature education study program STKIP-PGRI Lubuklinggau. The method used by the Research \& Development $(R \& D)$ model of Dick \& Carey with stages, 1$)$ analysis of needs and goals; 2) learning analysis; 3) analysis of learning (students) and context; 4) formulating performance goals; 5) developing instruments; 6) develop learning strategies; 7) developing and choosing learning materials; 8) design and conduct formative evaluations; 9) make revisions; 10) summative evaluation. The results of the study, the percentage of small group trial questionnaire of $92.78 \%$ included in the very positive category. Large group trials based on a questionnaire given to students get a very positive response with a percentage of $91.15 \%$, the results of the test of the ability 
of students after using the module module 10 subjects got very good grades with a score of 8-10 the percentage of $38.46 \%$, as many as 8 people who scored $6.6-7.9$ with a good category and a percentage of $30.77 \%$, the number of students who get enough grades only 4 people with a score of 6 or only $15.38 \%$, and students who score less as many as 4 people with a range of values from 4.6 to 5.5 or by $15.38 \%$. Conclusions, the development of contextual lecturer modules based on students' contextual study programs in Indonesian language and literature education in the category of very good and practical for students to use.

Keywords: Contextuality, Modules, Pewara Course.

\section{PENDAHULUAN}

Pembelajaran di Perguruan Tinggi menitik beratkan pada keterampilan proses. Hal ini sesuai dengan salah satu karateristik pembelajaran di Perguruan Tinggi yaitu "Integratif, capaian pembelajaran lulusan diraih melalui proses pembelajaran yang terintegrasi untuk memenuhi capaian pembelajaran lulusan secara keseluruhan dalam satu kesatuan program melalui pendekatan antardisiplin dan multidisiplin" (Marhaeni, et.al. 2018). Pembelajaran di Perguruan Tinggi khususnya pada Program Studi Bahasa dan Sastra Indonesia STKIP PGRI Lubuklinggau, sudah menggunakan kurikulum KKNI (Kerangka Kualifikasi Nasional Indonesia) dimana banyak matakuliah yang berganti dari kurikulum KTSP yang selama ini digunakan. Banyaknya matakuliah baru membuat dosen harus mampu berfikir kritis untuk menciptakan alat-alat pembelajaran yang kreatif dan inovatif baik dari sisi pendekatan pembelajaran, metode pembelajaran, bahan ajar maupun media pembelajaranya. Salah satu matakuliah pada kurikulum KKNI adalah matakuliah Pewara, yang merupakan matakuliah baru dengan bobot 3 SKS.

Matakuliah Pewara berkonsentrasi pada keterampilan berbicara di depan umum. Capaian pembelajaran lebih dominan pada keterampilan pembawa acara pada situasi formal, semi formal dan non-formal. Deseri (2010) menjelaskan pewara adalah mengendalikan upacara agar berjalan baik, tertib, meriah dan aman. Sedangkan Nuraeni (Rakhmat, 2016) menjelaskan jika pembawa acara yaitu orang yang bertanggung jawab penuh dalam kelangsungan sebuah acara sehingga sukses dan tidaknya acara bergantung pada pembawa acara. dengan adanya matakuliah Pewara ini nantinya mahasiswa akan mampu menerapkanya dalam kegiatan sehari-hari di dalam kehidupan bermasyarakat. Oleh sebab itu bahan ajar matakuliah ini harus mampu memotifasi mahasiswa untuk 
belajar. Bahan ajar yang baik akan mengarahkan pada pendalaman materi dan mengarahkan pada tercapainya capaian pembelajaran di kelas.

Hasil penelitian Nugroho, et.al (2019) menyatakan bahan ajar bisa menulis pantun telah, valid, praktis dan efektif untuk digunakan. Bahan ajar harus sesuai dengan karateristik dari peserta didik, bisa kontekstual ataupun kearifan lokal. Hal ini samahalnya dengan kearifan lokal yaitu dengan suatu gagasan, kebijakan di daerah tertentu yang diikuti masyarakat di daerah tersebut (Istiqomah dan Kusdiana, 2018). Selanjutnya (Citraningrum, 2016) pendekatan kontekstual dipilih dalam penelitian pengembangan karena pendekatan seperti ini merupakan pendekatan yang mampu melibatkan peserta didik untuk berfikir melalui konteks yang ada di lingkungan sekitar. Berdasarkan hal tersebut peelitian ini akan memfokuskan pada sumber ajar yang ada di sekitar lingkungan mahasiswa, sehingga lebih mudah memahaminya.

Namun pada penelitian ini mengembangkan modul pewara, berkonsentrasi pada keterampilan berbicara di depan umum, sehingga mahasiswa akan mampu menerapkanya dalam kegiatan sehari-hari di dalam kehidupan bermasyarakat. Penelitian yang penulis lakukan memiliki kelebihan pada produk yang dikembangan. Produk yang dikembangkan digunakan mahasiswa sehingga lebih kompleks sedangkan penelitian terdahulu lebih terfokus pada siswa sehingga produk lebih sederhana.

\section{METODE PENELITIAN}

Pengembangan model bahan ajar menggunakan Dick \& Carey terdapat sepuluh langkah menurut model Dick and Carey, yaitu: 1) analisis kebutuhan dan tujuan; 2) analisis pembelajaran; 3) analisis pembelajar (siswa) dan konteks; 4) merumuskan tujuan performansi; 5) mengembangkan instrument; 6) mengembangkan strategi pembelajaran; 7) mengembangkan dan memilih bahan pembelajaran; 8) merancang dan melakukan evaluasi formatif; 9) melakukan revisi; 10) evaluasi sumatif. Berdasarkan keterbatasan waktu Penelitian kontektualitas modul matakuliah keperwaraan pada mahasiswa prodi. Pendidikan bahasa dan sastra Indonesia STKIP-PGRI Lubuklinggau hanya melalui 8 tahapan.

Instrumen yang digunakan dalam penelitian ini yaitu wawancara, angket (kuesioner), dan tes. Angket digunakan untuk menganalisis data kuantitatif respon mahasiswa terhadap modul Pewara, skor data akan diubah menjadi kategori data kualitatif, sedangkan tes kemampuan sebagai data kuantitatif berupa tes berdasarkan 
per-sub bab materi akan dideskripsikan dalam bentuk perhitungan deskriptif. Peneliti melakukan validasi modul yang terdiri dari validasi desain, kebahasaan dan materi dengan tujuan untuk memperoleh kualitas bahan ajar yang baik.

\section{HASIL PENELITIAN}

\section{Analisis Kebutuhan dan Tujuan}

Langkah pertama yang dilakukan dalam model ini yaitu menganalisis kebutuhan suatu meteri pembelajaran untuk menentukan produk yang akan dikembangkan. Berdasarkan analisis kebutuhan dari hasil identifikasi kebutuhan bahan ajar matakuliah Pewara, minim sumber sehingga proses pembelajaran kurang menarik dan penggunaan bahan ajar yang tidak sesuai dengan lingkungan sekitar mahasiswa sehingga kurang memotivasi belajar.

\section{Analisis Pembelajaran}

Tahap kedua yaitu melakukan analisis pembelajaran, sehingga peneliti mengetahui kurikulum yang digunakan. Kurikulum yang digunakan di STKIP-PGRI Lubuklinggau yaitu kurikulum KKN (Kerangka Kualifikasi Nasional Indonesia), salah satu mata kuliah di prodi. Pendidikan bahasa dan sastra Indonesia yaitu Pewara dengan bobot 3 SKS.

\section{Analisis Siswa dan Konteks}

Peneliti kemudian melakukan analisis mahasiswa dan konteksnya. Peneliti menggunakan satu kelas di semester IV untuk uji coba prototipe dan uji coba kelompok kecil serta kelompok besar.

\section{Mengembangkan Instrumen}

Instrumen merupakan alat ukur yang digunakan untuk mengetahui tercapai tidaknya tujuan yang diharapkan. Instrumen dapat berupa soal latihan.

\section{Mengembangkan Strategi Pembelajaran}

Berdasarkan beberapa penjelasan di atas sudah tergambar strategi yang digunakan dalam pengimplementasian modul matakuliah Pewara berbasis kontekstual mahasiswa program studi pendidikan bahasa dan sastra Indonesia STKIP-PGRI Lubuklinggau. 


\section{Mengembangkan dan Memilih Bahan Pembelajaran}

Modul matakuliah Pewara berbasis kontekstual ini berdasarkan kurangnya motivasi belajar siswa. Pengembangan modul bahan ajar matakuliah Pewara ini berdasarkan lingkungan yang dekat dengan mahasiswa. Diharapkan agar mahasiswa lebih meningkatkan kembali minat belajar dan motivasinya untuk mencapai hasil akhir yang baik.

\section{Evaluasi Formatif dan Revisi}

\section{Evaluasi Ahli}

Validator kebahasaan untuk validasi modul matakuliah Pewara berbasis kontekstual mahasiswa program studi pendidikan bahasa dan sastra Indonesia STKIPPGRI Lubuklinggau yaitu Dr. Noermanzah, M.Pd. Beliau adalah dosen prodi bahasa dan sastra Indonesia di STKIP-PGRI Lubuklinggau. Angket yang diberikan adalah angket terbuka sebanyak lima pertanyaan. Selain itu terdapat juga kolom saran yang diberikan guna perbaikan bahan ajar yang divalidasi. Pemahaman bahasa masuk dalam kategori cukup dari validator kebahasaan. Berdasarkan penghitungan komponen kelayakan kebahasaan di atas maka dapat disimpulan komponen kelayakan kebahasaan masuk dalam kategori sangat baik, dengan persentase $82 \%$.

Selain evaluasi ahli kebahasaan terdapat juga evaluasi ahli materi yang merupakan dosen di STKIP-PGRI Lubuklinggau sekaligus kepala prodi pendidikan bahasa dan sastra Indonesia yaitu Dr. Satinem, M.Pd. Tujuan dari evaluasi materi adalah untuk mengetahui layak dan akurat tidaknya materi modul matakuliah Pewara berbasis kontekstual. Cara yang dilakukan dalam evaluasi ahli sama dengan cara yang diberikan terhadap evaluasi kebahasaan yaitu menggunakan angket terbuka. Berdasarkan hasil dari validasi tim ahli materi diketahui bahwa modul matakuliah Pewara berbasis kontekstual berkategori baik. Kesimpulan komponen kelayakan isi/materi termasuk dalam kategori baik, dengan persentase $74,29 \%$.

Validator ahli desain modul matakuliah Pewara berbasis kontekstual adalah salah satu dosen dari STKIP-PGRI Lubuklinggau yang berkompeten dalam bidang desain yaitu Bapak Dodik Mulyono, M.Pd. sebagai dosen Program Studi Pendidikan Matematika. Kesimpulan komponen kelayakan desain termasuk dalam kategori sangat 
baik, dengan persentase $80 \%$. Kesimpulan seluruh komponen termasuk dalam kategori sangat baik, dengan persentase $83,33 \%$.

\section{Evaluasi Prototipe}

Evaluasi prototipe adalah uji coba awal modul matakuliah Pewara berbasis kontekstual. Uji coba prototipe dilakukan pada 2018, uji coba ini dilakukan terhadap 4 orang mahasiswa dengan langkah-langkah sebagai berikut:

1. Mahasiswa membaca dan mengamati modul matakuliah Pewara berbasis kontekstual

2. Mahasiswa memahami materi yang diberikan dan menjawab pertanyaan secara lisan dari modul matakuliah Pewara berbasis kontekstual, setiap per-sub bab. Apabila mahasiswa dapat menjawab dengan benar maka dapat disimpulkan tingkat keterbacaan mahasiswa masuk dalam kategori tinggi, artinya produk modul matakuliah Pewara berbasis kontekstual yang disajikan mudah dimengerti.

Berdasarkan wawancara terhadap tiga orang siswa mengatakan bahwa penampilan keseluruhan modul matakuliah Pewara berbasis kontekstual dikatakan baik, mudah dipahami, sangat jelas, dan sesuai dengan kontekstual, kemudian gambar yang diberikan manarik, warna yang jelas dan terang, ada juga yang mengatakan bagus, mudah dipahami, karena berbasis kontekstual sehingga ketika memahami materi modul matakuliah Pewara berbasis kontekstual tertarik untuk mempelajarinya.

Selanjutnya tentang pendapat siswa yang berkaitan dengan isi materi dalam modul matakuliah Pewara berbasis kontekstual, menurut mahasiswa mudah dipahami, mudah dimengerti, dan mudah diingat. Hal ini dikarenakan telah melalui validator tim ahli yang sangat mempengaruhi kualitas modul matakuliah Pewara berbasis kontekstual. Berdasarkan uji coba prototipe peneliti tidak perlu merevisi kembali modul matakuliah Pewara, maka peneliti melakukan tahap uji coba selanjutnya.

\section{Uji Coba Kelompok Kecil}

Uji coba kelompok kecil dilakukan pada sembilan mahasiswa semester IV prodi. Pendidikan bahasa dan sastra Indonesia STKIP-PGRI Lubuklinggau.

Uji coba kelompok kecil dilakukan dengan memperhatikan terlebih dahulu modul matakuliah Pewara berbasis kontekstual, uji coba ini hampir sama dengan uji coba prototipe karena sama-sama bertujuan mengetahui kepraktisan bahan ajar yang 
dikembangkan. Pembeda uji coba prototipe dan kelompok kecil adalah alat ukur yang digunakan, jika prototipe menggunakan alat ukur berupa pertanyaan wawancara maka uji coba kelompok besar menggunakan alat ukur berupa angket yang terdiri dari sepuluh pertanyaan.

Hasil penghitungan angket uji coba kelompok kecil terhadap modul matakuliah Pewara berbasis kontekstual dapat dilihat pada penghitungan di atas. Kesimpulan dari respon siswa melalui angket uji coba menunjukan hasil sangat positif terhadap modul matakuliah Pewara berbasis kontekstual dengan persentase 92,78\%. Sehingga modul matakuliah Pewara berbasis kontekstual sudah praktis dan dapat digunakan untuk uji coba kelompok besar tanpa adanya perbaikan karena tidak ada kritikan dari mahasiswa.

\section{Uji Coba Kelompok Besar}

Pelaksanaan uji coba kelompok besar pada semester IV modul matakuliah Pewara berbasis kontekstual yang terdiri dari 26 siswa. Uji coba kelompok besar bertujuan untuk mengetahui valid dan efektif tidaknya modul matakuliah Pewara berbasis kontekstual. Setelah melakukan tes kemampuan, kemudian mahasiswa mengisi angket yang diberikan peneliti kepada mahasiswa.

Berdasarkan penghitungan angket kelompok besar di atas tentang modul matakuliah Pewara berbasis kontekstual, memperoleh hasil 91,15\% sehingga dapat disimpulkan bahwa respon mahasiswa terhadap modul matakuliah Pewara berbasis kontekstual mahasiswa program studi pendidikan bahasa dan sastra Indonesia STKIPPGRI Lubuklinggau sangat baik.

\section{PEMBAHASAN}

\section{Proses Desain Pengembangan Matakuliah Pewara Berbasis Kontekstual}

Mengembangkan modul matakuliah Pewara berbasis kontekstual dilakukan setelah proses analisis data dan identifikasi pembelajaran. Analisis data dilakukan semester IV prodi. Pendidikan bahasa dan sastra Indonesia STKIP-PGRI Lubklinggau. Tahap analisis kebutuhan dilakukan untuk mengetahui kebutuhan modul pada salah satu materi matakuliah Pewara.

Proses pembuatan cover bahan ajar modul matakuliah Pewara berbasis kontekstual, berdasarkan inspirasi dari peneliti sendiri. Gambar yang menjadi desain 
cover modul memiliki kedekatan dengan mahasiswa yang dapat menimbulkan motivasi belajar bagi mahasiswa. Hal ini sesuai dengan pendapat Prastowo (2011) "bahan ajar merupakan segala bahan yang disusun secara sistematis, menampilkan kompetensi yang dikuasai peserta didik dan digunakan dalam proses pembelajaran dengan tujuan perencanaan dan penelaahan implementasi pembelajaran. Jadi bahan ajar harus memiliki kedekatan psikologis dari peserta didiknya dengan tetap memperhatikan kompetensi dan tujuan pembelajaran.

Latar belakang awal modul matakuliah Pewara berbasis kontekstual yang peneliti desain memiliki perbedaan sebelum diresvisi. Latar belakang awal yang peneliti buat berdasarkan unsur keindahan, namun berdasarkan masukan dari tim ahli bahwa latar belakang yang digunakan harus disesuaikan dengan topik dalam modul. Sehingga peneliti melakukan perbaikan dengan mencari latar belakang yang bernuansa kontekstual untuk digunakan dalam modul matakuliah Pewara yang berbasis kontekstual. Hal ini sesuai dengan salah satu fungsi modul adalah bahan ajar yang mampu mengantikan fungsi pendidik dalam menyampaikan materi pembelajaran dan disesuaikan dengan umur, karateristik dan kemampuan siswa (Prastowo, 2011). Jadi pengembangan matakuliah pewara berbasis kontekstual diharapkan mampu menarik minat belajar karena sudah disesuaikan dengan lingkungan peserta didik.

\section{Valid, Praktis, dan Efektif Model}

Evaluasi kevalidan dalam bahan ajar teks deskripsi berbasis dakwah, dilakukan dengan mengadakan evaluasi tim ahli. Evaluasi tim ahli dilakukan oleh tiga orang ahli, yaitu ahli desain, ahli kebahasaan dan ahli materi. Hasil evaluasi tim ahli berupa angket menjadi standar patokan apakah model bahan ajar yang dikembangkan valid atau tidak. Berdasarkan analisis dan perhitungan nilai angket dari validasi tim ahli, modul matakuliah Pewara tergolong dalam kategori sangat baik dengan persentase 83,33\%, artinya bahan ajar teks deskripsi berbasis dakwah telah valid.

Kepraktisan dari modul matakuliah Pewara berbasis kontekstual, dilakukan dengan uji coba prototipe atau evalusi one to one dan uji coba kelompok kecil. Perbedaan dari dua uji coba tersebut terletak pada alat ukurnya, yaitu uji coba prototipe dilakukan dengan wawancara terhadap tiga orang mahasiswa, dengan menjawab sejumlah pertanyaan yang mengandung tentang kepraktisan penggunaan modul 
matakuliah Pewara berbasis kontekstual. Sedangkan uji coba kelompok kecil dilakukan dengan pemberian angket mengenai kepraktisan modul matakuliah Pewara berbasis kontekstual, terhadap sembilan orang mahasiswa. Dengan demikian modul matakuliah Pewara berbasis kontekstual pada tahap uji coba prototipe dan uji coba kelompok kecil, tergolong sangat positif dengan persentase 92,78\%. Berdasarkan persentase tersebut modul matakuliah Pewara berbasis kontekstual sudah praktis untuk digunakan.

Berdasarkan penghitungan angket kelompok besar di atas tentang modul matakuliah Pewara berbasis kontekstual, memperoleh hasil $91,15 \%$ sehingga dapat disimpulkan bahwa respon mahasiswa terhadap modul matakuliah Pewara berbasis kontekstual mahasiswa program studi pendidikan bahasa dan sastra Indonesia STKIPPGRI Lubuklinggau sangat baik.

\section{SIMPULAN}

Pengembangan modul matakuliah pewara berbasis kontekstual mahasiswa program studi pendidikan bahasa dan sastra Indonesia STKIP PGRI Lubuklinggau, dalam kategori sangat baik dan praktis untuk digunakan mahasiswa

\section{DAFTAR PUSTAKA}

Citraningrum. D,.A. (2016). Pengembangan Bahan Ajar Menyimak-Berbicara untuk Siswa SMP dengan Pendekatan Kontekstual. Jurnal: Unmuhjember, 1(2), 130139

Deseri, E. (2010). Menjadi Protokol dan MC. Sumatera Selatan: Putra Penuntun.

Istiqomah.W.N. (2018). Pengembangan Bahan Ajar Pembelajaran Berbicara Berbasis Kearifan Lokal melalui Permainan Bahasa di Sekolah Dasar. Jurnal: Pedadidaktika (Jurnal Ilmiah Bahasa di Sekolah Dasar) 5(4)

Marhaeni,A. A. I. (2018). Bahan Ajar Pekerti. Depok: Raja Grafindo Persada.

Nugroho.N, (2019). Pengembangan Bahan Ajar LKS Menulis Pantun Berbasis Kearifan Lokal Siswa Kelas VII SMP Xaverius Tugumulyo. Jurnal: KEMBARA (Jurnal Keilmuan Bahasa, Sastra dan Pengajaranya), 5(1), 1-12

Prastowo, A. (2011). Panduan Bahan Ajar Inovatif. Yogyakarta: Diva Press.

Rakhmat, J. (2016). Public Speaking (Kunci Sukses Berbicara di Depan Publik. Yogyakarta: Pustaka Pelajar. 